\title{
La trayectoria poética de Rubén Darío a la luz del parnasianismo. II: de París a Nicaragua
}

\author{
Miguel Ángel Feria ${ }^{1}$
}

Resumen. La poesía de Rubén Darío puede dividirse en dos períodos bien diferenciados si se estudia a la luz de la influencia francesa: antes de 1893, fecha de la primera visita del nicaragüense a París, y luego todo el período posterior marcado por títulos capitales como Prosas profanas y Cantos de vida y esperanza. Una vez alcanzado el clímax de un primer modernismo exclusivamente parnasiano, aquel de las dos primeras ediciones de $A z u l . .$. . Darío asimila en la capital francesa la literatura decadente-simbolista. Desde entonces, la obra dariana y con ella todo el modernismo poético del mundo hispánico virarán hacia la adopción de un nuevo canon que, si bien no habrá de abandonar jamás cierta filiación parnasiana, hallará en otros modelos expresivos de modernidad más plena la motivación adecuada para poner punto y final al siglo XIX en las letras españolas.

Palabras clave: Rubén Darío; Modernismo; Fin de Siglo; poesía; Parnasianismo.

\section{[en] Rubén Darío's poetic trajectory in the light of parnasianism. II: from Paris to Nicaragua}

\begin{abstract}
Rubén Darío's poetry can be divided into two well different periods, taking into account the French influence : before 1893, when he first visited Paris, and the period after that, marked by capital titles such as Prosas profanas and Cantos de vida y esperanza. Once the exclusively Parnassian first Modernism had reached its climax -the two first Azul editions period- Darío assimilated in the French capital the Decadent-Symbolist literature. From then, Darío's work and with it, the whole poetic Hispanic Modernism changed into the adoption of a new canon. Although this one would never abandon some Parnassian connections, the adequate motivation to end $19^{\text {th }}$ century in the Hispanic letters would be found in other expressive models of a more complete modernity.
\end{abstract}

Keywords: Rubén Darío; Hispanic Modernism; Fin de siècle; poetry; Parnassianism.

Sumario. 1. Rubén Darío en Buenos Aires (1893-1898). Los raros. Prosas profanas. 2. Rubén Darío en Europa (1898-1916).

Cómo citar: Feria, M.A. (2017) La trayectoria poética de Rubén Darío a la luz del parnasianismo. II: de París a Nicaragua, en Anales de Literatura Hispanoamericana 46, 159-181.

1 Universidad Complutense de Madrid/Université Paris Diderot-Paris 7, España/Francia.

E-mail: miguelangelferia@gmail.com 


\section{Rubén Darío en Buenos Aires (1893-1898). Los raros. Prosas profanas}

Cuando Rubén Darío desembarca en Buenos Aires en 1893 no era yermo, ni mucho menos, el terreno literario que pisaba. El desarrollo urbano, industrial y cultural de la ciudad desde la década de los 60, el impulso renovador de la Generación del Ochenta, la fundación de la Facultad de Filosofía y Letras y del Ateneo en 1892, el florecimiento del periodismo, y, en fin, el ambiente cosmopolita que dominaba en la ciudad propiciaron el caldo de cultivo ideal para que Buenos Aires se convirtiera, con la llegada del nicaragüense, en la capital continental del Modernismo, en su "Cosmópolis". Por otra parte, el joven Darío que en agosto de 1893 se instala en Argentina como Cónsul de Colombia ya no era sólo aquel aprendiz de parnasiano de su periplo por Centroamérica y Chile: había visitado París ese mismo verano, y allí había tomado conciencia, de la mano de Gómez Carrillo, del verdadero alcance del Simbolismo, hecho decisivo para la gestación de una manera poética nueva que alcanzará su apogeo durante los años bonaerenses.

Aclamado por La Prensa y La Nación y por los jóvenes a la vanguardia de la literatura argentina agrupados en torno a La Nueva Revista (1893-1894), agasajado en el Ateneo con un deslumbrante banquete de recepción, Rubén Darío fue saludado en Buenos Aires como una suerte de profeta de la naciente estética modernista ${ }^{2}$. Pronto se incorporó a la nómina de La Nación como redactor, si bien ya venía colaborando con el célebre diario desde 1889, y no dudó en beneficiarse de su tribuna para difundir a los cuatro vientos la buena nueva. Así, con el título de Los raros, Darío va forjando desde las páginas del periódico más importante de la República el canon y el ideario modernista. La célebre serie de retratos literarios, que acabaría conformando el volumen de 1896, refleja ante todo cómo Darío, durante sus años en Buenos Aires, ha ido ampliando su abanico de preferencias culturales y literarias y modulando su discurso poético hacia un modernismo ecléctico, un modernismo cuyos componentes parnasianos irían siendo progresivamente completados con otras influencias. El decadentismo, el simbolismo, el wagnerianismo, y en fin, todas las máscaras, las figuras, las formas y los mitos del Fin de Siglo eran moneda de curso legal en Buenos Aires, a lo que debe sumarse que tras su paso por París, Rubén Darío hubo terminado por asimilar que el Parnasse contemporain no era precisamente la punta de lanza de las nuevas corrientes poéticas. Nacía una poesía heterogénea y radicalmente nueva a la que aún no se sabía si llamar "decadentismo", "simbolismo" o simplemente "modernismo", y Rubén era plenamente consciente de ello: "Una nueva escuela

\footnotetext{
Dirigida por José Ceppi, La Nueva Revista supuso un anticipo del modernismo beligerante que en seguida encarnarían distintas publicaciones de breve pero intenso recorrido. Allí colaboraron, entre otros, las jóvenes promesas de la poesía en Argentina como Ricardo Jaimes Freyre o Leopoldo Díaz. La venida del poeta nicaragüense fue celebrada en su seno de esta guisa: "Romántico, parnasiano, decadente... llamadlo como queráis; lo cierto es que él ha hecho de la férrea lengua española, un idioma exquisito. Azul... es una revolución". Junto a La Nueva Revista, una de las primeras publicaciones argentinas que presentó a Rubén Darío fue Artes y Letras (1892-1893), semanario que a pesar de su tendencia católica y conservadora cedió su espacio a la renovadora lírica del nicaragüense y de otros poetas como L. Díaz o el malagueño Salvador Rueda, al tiempo que presentó alguna traducción de Heredia. Caben ser destacadas en estos años otras revistas como El Búcaro Americano (1896-1909), de tendencia feminista, donde colaboraron tanto Darío como el resto de modernistas de postín y se tradujo a Ibsen o a Baudelaire, o La Revista Moderna (1897), que además de publicar a Darío o a Azorín, contó en sus páginas con traducciones de autores tan modernos como Maeterlinck o Mallarmé. Cf. Englekirk, 1961: 23; Lafleur et al., 1962: 17 y ss.
} 
acababa de surgir, opuesta [...] a la corriente poderosa de Víctor Hugo y sus hijos los parnasianos [...]. Tales fueron los decadentes, unidos en un principio, y después separados por la más extraña de las anarquías, en grupos, subgrupos, variados y curiosos cenáculos" ["Jean Moréas", Los raros]. Entre los panegíricos de Los Raros, sólo uno se ocupa de un autor del Parnasse, el maestro Leconte de Lisle. Son, a grandes rasgos, decadentes y simbolistas los que ahora ofician en los altares de la lírica dariana, lo cual tampoco significa que Darío renegara, ni mucho menos, del parnasianismo. Integradas a lo largo de los diferentes ensayos, son múltiples las citas y alusiones a los Leconte de Lisle, Gautier, Banville o Mendès con las que se dignifica a la Escuela, si bien en todo momento se sigue considerando a Víctor Hugo "el más grande de los poetas", distinción con la que Darío también honrará a partir de ahora a Paul Verlaine. El culto al Parnaso propio de sus años de aprendizaje irá moderándose manifiestamente en Buenos Aires, y la serie de Los raros es un buen indicador de ello. A propósito de Édouard Dubus, Rubén tacha a los parnasianos de simples "albañiles impecables", mientras que en el artículo sobre Paul Adam, no duda en condenar de manera explícita a su antes admiradísimo Catulle Mendès, "cuya pornografía de color de rosa no está ya de moda", y a François Coppée, a quien llama "inválido lírico metido a sacristán", autor de "tiradas tricolores" dirigidas exclusivamente al "pueblo".

En cualquier caso, el artículo dedicado a Leconte de Lisle vio la luz en $L a$ Nación poco después de la muerte del poeta en julio de 1894, y se trata sin duda de uno de los homenajes más extensos y sinceros de toda la serie. Del "pontífice del Parnaso", Rubén comienza destacando una serie de cualidades definitorias que extrapola al conjunto de los miembros de la Escuela, tales el "soplo épico", la "impasibilidad casi religiosa", el exotismo y la "magnificencia monumental estatuaria", producto del "culto de la forma", para en seguida encargarse del análisis del conjunto de su obra, evidenciando, en este sentido, un estudio y una veneración a prueba de dudas. Basándose luego en La Légende du Parnasse Contemporain de Catulle Mendès, obra que cita traduciendo extensos párrafos para la ocasión, Darío calibra la importancia capital de la Escuela parnasiana en el devenir de la última lírica francesa, para finalmente concluir con una interesante reflexión sobre el escaso eco que un poeta de la talla de Leconte de Lisle había tenido en las letras hispánicas: "En lengua castellana apenas es conocido Leconte de Lisle. Yo no sé de ningún poeta que le haya traducido, exceptuando al argentino Leopoldo Díaz, mi amigo muy estimado..."3. No fue aquel el único texto en el que el poeta nicaragüense se ocupaba de la figura del maestro. El 7 de enero de 1895 publicó en La Nación "El sillón de Leconte de Lisle. La juventud y la Academia. Lo que dijo Charles Morice. Verlaine y Zola", un escueto pero peculiar razonamiento sobre quién habría de ocupar el sillón vacante en la Academia francesa tras el fallecimiento del parnasiano. Para Darío, y una vez expuesta la grandeza de Leconte de Lisle en términos análogos a los del artículo anterior, la ausencia del "sacerdote augusto del arte sagrado", del "maestro precioso, jefe de la única escuela que tiene algún porvenir: la escuela de la perfección" debería ser

3 Amén de las versiones de Díaz, recopiladas más tarde en volumen -Traducciones (1897)-, cuando Darío pronuncia estas palabras ya algunos poemas de Leconte de Lisle había sido traducidos al español por Aurelia Castillo de González en Cuba, por Luis López Méndez en Venezuela, por Ricardo Catarineu en España, por Balbino Dávalos en México y por Francisco Soto y Calvo en la propia Argentina. 
cubierta por Zola o por Verlaine, aún a sabiendas de que, por cuestiones extraliterarias, ninguno de los dos se vería nunca honrado con tal distinción. ${ }^{4}$

La figura de Leconte de Lisle, sin embargo, será la única del Parnasse contemporain que tenga cabida en la galería de maestros modernos de Los raros, y tras ella, son los semblantes de simbolistas y decadentes los que ocupan el lugar más destacado: Paul Verlaine -"casi desconocido en España" y "el más grande de todos los poetas de este siglo"-, Villiers de L'Isle-Adam, Jean Richepin, Jean Moréas, Laurent Tailhade, Édouard Dubus, Théodore Hannon, Lautréamont, Paul Adam, el portugués Eugenio de Castro... Es atendiendo a esta orientación como debe reseñarse la naturaleza y relevancia de uno de los hitos del modernismo en Argentina, la Revista de América (1894). Fundada por el propio Rubén Darío y su amigo el poeta de origen boliviano Ricardo Jaimes Freyre, la Revista de América tuvo una trayectoria muy corta, apenas tres números, lo suficiente sin embargo para influir notablemente en la formación y desarrollo del Modernismo en Argentina y en gran parte del continente americano. Entre sus objetivos, expuestos en "Nuestros propósitos", texto firmado al alimón por los redactores y que abría el primer número, resuena gran parte del credo que Gautier defendiese en el célebre Prefacio a Mademoiselle de Maupin: "Ser el órgano de la generación nueva que en América profesa el culto del Arte puro y busca la perfección ideal. [...] Luchar porque prevalezca el amor a la divina Belleza, tan combatido hoy por invasoras tendencias utilitarias" $"$. Un Arte puro, pero decididamente concebido en el seno de lo decadente y lo simbolista. Ya en ese primer número -y en los sucesivos-, se incluye un estudio de capital importancia para la recepción y comprensión del simbolismo y para su definitiva escisión del parnasianismo en la todavía desorientada crítica literaria argentina e hispanoamericana: se trata de "Los poetas jóvenes de Francia”, a cargo del guatemalteco Enrique Gómez Carrillo, así como un ensayo de Darío dedicado a "Un esteta italiano. Gabriel D'Annunzio". Las únicas muestras de parnasianismo presentes en la Revista de América corren a cuenta de Leopoldo Díaz: un "Camafeo" y la traducción de "La tristeza del diablo" de Leconte de Lisle (Cf. Carter, 1959: 35; 1968: 46 y ss).

En el ojo del huracán de la revolución modernista, y ante la inminente salida de Prosas profanas, el 27 de noviembre de 1896 publicaba Rubén Darío en La Nación "Los colores del estandarte", apología, con visos de manifiesto, de la nueva literatura. Por vez primera, y a propósito de $A z u l . .$. , nuestro poeta se declaraba, abiertamente, el iniciador del Modernismo en lengua española: "Y he aquí cómo, pensando en francés y escribiendo en castellano [...] publiqué el pequeño libro que iniciaría el actual movimiento literario americano, del cual saldrá, según José

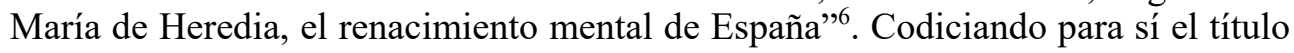
de patriarca de las nuevas letras, y obliterando para ello a otros modernistas precursores de la talla de Martí, Julián del Casal o Gutiérrez Nájera, ya fallecidos y

4 "El sillón de Leconte de Lisle. La juventud y la Academia. Lo que dijo Charles Morice. Verlaine y Zola" puede consultarse en las Obras completas editadas por Mundo Latino en Madrid (1917-19), tomo XX, Prosa dispersa.

5 "Nuestros propósitos" sería luego recolocado por Darío a manera de prólogo en la primera edición de Los Raros, París, Tip. de "La Vasconia", 1896.

6 La mención a José María de Heredia permanece en el misterio, pues no hemos podido localizar ese supuesto hipotexto en el que el parnasiano francés de origen cubano aluda a Darío, a su Azul... ni a a "renacimiento mental en España" alguno. 
que por tanto nada podían objetar, Rubén coloca su $A z u l \ldots$ en el punto de partida del renacimiento de la lírica española. Pero lo realmente importante del ensayo, lo más controvertido, radica en la precisión con la que su propio autor no duda en calificar su libro de puramente parnasiano, confiriendo así al Parnasse un papel fundamental en la génesis del Modernismo:

El $A z u l \ldots$ es un libro parnasiano y, por tanto, francés. En él aparecen por primera vez en nuestra lengua el "cuento" parisiense", la adjetivación francesa, el giro galo injertado en el párrafo clásico castellano; la chuchería de Goncourt, la câlinerie erótica de Mendès, el encogimiento verbal de Heredia, y hasta su poquito de Coppée.

En seguida no tardará Rubén en reconocer, tras lo parnasiano, otros ingredientes de no menor valía en la conformación de la nueva poética, aunque, eso sí, confesando siempre que no es hasta su paso por París en 1893 cuando realmente toma contacto y asimila el espíritu de los "llamados decadentes" como Verlaine, Mallarmé, Moréas, Huysmans o Régnier. Un espíritu cuya radical libertad, amor a la belleza "clara, simbólica, arcana" y tajante individualismo, contrario a cualquier ortodoxia, definen en última esencia la naturaleza de la poética modernista tal como la concibiera Darío y, siguiendo su ejemplo, el común de los poetas hispánicos desde entonces: "Sé tú mismo: ésa es la regla".

"Los colores del estandarte" añade un elocuente capítulo al dinámico Buenos Aires literario de 1896, auténtico hervidero de debates, polémicas y porfías alrededor del modernismo del que participa una de las revistas de mayor enjundia en este sentido, La Biblioteca (1896-1898), fundada y dirigida por Paul Groussac. En un momento en el que desde los círculos más conservadores se lanzaban todo tipo de pullas al nicaragüense y a sus seguidores, Groussac, sin ser modernista, trasladó a su revista gran parte de su carácter insobornable, adusto e independiente, publicando trabajos tanto de los autores consagrados de la Generación del Ochenta como de los prometedores Darío o Leopoldo Lugones. Groussac, que conocía de primera mano a todos los poetas franceses de su siglo, se sentía más capacitado que nadie para discernir las voces de los ecos, y puso todo su empeño en aleccionar a Rubén Darío, cuyo talento supo reconocer, frente a los peligros de las modas parisinas. Groussac veneraba a los grandes parnasianos con el mismo ímpetu con el que abominaba de los decadentes y simbolistas de última hora, y así se lo hizo entender al nicaragüense a propósito de Los raros y del "Coloquio de los centauros", poema que se publicó en La Biblioteca en su segundo número, el 2 de julio de 1896. Para el crítico franco-argentino, Los raros era un "despilfarro" que sólo podía resultar interesante para "algunos decadentes de botón", un batiburrillo donde "altas individualidades como Leconte de Lisle, Ibsen, Poe y el mismo Verlaine, respiran el mismo incienso y se codean con los Bloy, d'Esparbés, la histérica Rachilde y otros ratés aún más innominados". En su opinión, el joven Darío, tras su aprendizaje parnasiano, había perdido el "claro discernimiento artístico" al quedar demasiado sugestionado por las últimas novedades del Barrio Latino, cuando "por mala fortuna vínole a las manos un tomo de Verlaine", hasta llegar a convertirse en triste "heraldo de pseudo-talentos decadentes, simbólicos, 
estetas"

Muy a finales de 1896 se imprimen definitivamente las Prosas profanas de Rubén Darío, cuya distribución no comenzaría, con toda probabilidad, sino a principios de 1897, si bien la inmensa mayoría de sus poemas había venido publicándose en distintos periódicos y revistas desde la llegada del poeta a la capital ( $C f$. Carilla, 1967: 67 y ss). Esto explica, en cierta medida, la versatilidad de una obra donde resuena toda la gama tonal del modernismo triunfante, aunque la voz cantante aún la lleve, quizás a pesar suyo, el Rubén parnasiano. Desde las memorables "Palabras liminares", la querencia por la pauta verlainiana queda patente, sí, pero por el Verlaine aún apegado al Parnasse de Poèmes saturniens (1866) y Fêtes galantes (1869) antes que por el realmente simbolista, maestro del matiz, de la asonancia sugerente y del verso desleído en música. No hay rastro alguno, por otra parte, de un Mallarmé o un Rimbaud. Estas "Palabras liminares" que Darío coloca en el pórtico de Prosas profanas recogen en sí uno de los principios fundacionales de la doctrina parnasiana: el escapismo, el exotismo temporal y espacial, la recreación lírica de tiempos heroicos y legendarios: "Yo detesto la vida y el tiempo en que me tocó nacer; y a un presidente de República no podré saludarle en el idioma en que te cantaría a ti, ¡oh Halagabal!, de cuya corte oro, seda, mármol- me acuerdo en sueños..."

Para el poema inaugural de Prosas profanas ya nos confiesa el propio Rubén, en Historia de mis libros, cuál había sido su guía: "En Era un aire suave [...] sigo el precepto del Arte Poética de Verlaine: De la musique avant toute chose". ¿Ha de ser considerado por ello un poema simbolista? Pensamos que no. Pese a que el nicaragüense estuviese tratando de incorporar la novedosa propuesta lírica de Verlaine, nos inclinamos a creer que, más que asimilarla, estaba tergiversándola con suma destreza, y que "Era un aire suave" se mantiene dentro de los márgenes de un parnasianismo exquisito y delicado en la estela musical de un Théodore de Banville. No es la semanticidad simbólica la que maneja Darío mediante sus serventesios consonánticos sobrealiterados, a pesar de la sutilidad de las imágenes, suscitadas en algunos casos por la sugestión sonora más allá de su expresión detallada -pero nunca prescindiendo de ella-. En este sentido, la factura de "Era un aire suave" concuerda en gran medida con algunas de las teorías con las que Banville había especulado ya en su Petit Traité de Poésie Française, obra que Darío conocía sobradamente, si no nos engañan sus alusiones a la misma con que

Tal como les ocurriera a los propios parnasianos, Paul Groussac no acertaba a calibrar cuáles eran las novedades que aportaba el simbolismo, y cuando se muestra respetuoso, hasta cierto punto, con las mismas, será precisamente por lo que pudiesen tener de origen parnasiano: "Lo único viable en el nuevo simbolismo francés -o no es nuevo, o no es simbólico. Verlaine es un parnasiano convertido, cuyos pocos versos realmente admirables [...] están vaciados en el molde de Hugo o Banville: podrían ser de un Coppée ingenuo y angustiado, que levantara el lamentable De profundis de su miseria. Lo propio diríamos de Vielé-Griffin, La Tailhède, Régnier, Wyzéwa y otros, presentes o futuros colaboradores de la Revue des Deux Mondes. [...] Por fin, el apocalíptico Mallarmé ha necesitado tornarse incomprensible, para dejar de ser abiertamente mediocre: su esoterismo verbal es el cierro secreto de un arca vacía”. $C f$. Groussac, 1896: 43 y ss.

8 Las palabras de Darío remiten directamente a estas otras que Gautier escribió en su relato "Une nuit de Cléopâtre" (1838): "Mais le spectacle du monde antique est quelque chose de si écrasant, de si décourageant pour les imaginations qui se croient effrénées et les esprits qui pensent avoir atteint aux dernières limites de la magnificence féerique, que nous n'avons pu nous empêcher de consigner ici nos doléances et nos tristesses de n'avoir pas été contemporain de Sardanapale, de Teglath Phalazar, de Cléopâtre, reine d'Égypte, ou seulement d'Héliogabale, empereur de Rome et prête du Soleil...". 
aderezó, aquí y allá, algunos de sus textos ${ }^{9}$. En cuanto a la ambientación del poema, cuya indeterminación espacio-temporal -"Yo el tiempo y el día y el país ignoro"- quizás hubiera disgustado al severo Leconte de Lisle, se aviene al gusto por algunos rasgos característicos de los cuentos de hadas que Catulle Mendès había incorporado en numerosas obras ${ }^{10}$. Por último, otro aspecto a destacar en este poema y en las restantes Prosas profanas es su selección léxica -"liras eolias", "sedosos trajes", "blancas magnolias", "tacón rojo"...-, heredera de aquella privilegiada por los parnasianos, y con mayor particularidad, por Gautier y Banville ${ }^{11}$.

En el catálogo panerótico que Darío despliega en el segundo poema, "Divagación", el engarce con la obra de Gautier no puede ser más explícito: "Gautier adoraba las princesas chinas". Al recurrir a una sensualidad oriental de procedencia intencionadamente gauteriana -recuérdense poemas como "Chinoiserie", en La comedie de la mort (1838)-, el poeta, en lugar de ocultarnos sus fuentes, prefiere, a manera de homenaje, precisarlas y amplificarlas al resto del repertorio. Erudito a la parnasiana, su helenismo, tal como en seguida nos confiesa, está pasado por el filtro francés de los Gautier, Banville o Mendès: "Amo más que la Grecia de los griegos / la Grecia de la Francia..."." Modelos análogamente parnasianos se le han atribuido a la célebre "Sonatina": "Gongorine", del cubano Augusto de Armas, por su factura ( $C f$. Henríquez Ureña, 1941: 301-344) o "Thestylis", de Leconte de Lisle, por su tema, guardan, en efecto, ciertas semejanzas con el poema rubeniano ( $C f$. Mapes, 1925: 93). En mi opinión, muchos de los motivos de la "Sonatina", y en particular su cierre, me parecen también deudores de un soneto de Edmond Rostand, "Vieux conte" -Les Musardises (1890)-: "Toute rose, elle dort son sommeil ingénu, / Car le Prince Charmant n'est pas encor venu / Qui doit la réveiller d'un baiser sur la bouche..."13. Sea como fuere, el cúmulo de paratextos, citas y homenajes, veladas alusiones,

9 Fragmentos como el siguiente ilustran sobremanera una concepción de la expresión poética inmediatamente anterior al simbolismo y particularmente cercana a la praxis dariana: "Ce n'est pas en décrivant les objets sous leurs aspects divers et dans leurs moindres détails que le vers les fait voir; ce n'est pas en exprimant les idées in extenso et dans leur ordre logique qu'il les communique à ses auditeurs, mais IL SUSCITE dans leur esprit ces images ou ces idées et pour les exciter il lui suffit en effet d'un mot...”. Banville, Théodore de. Petit Traité de Poésie Française, pág. 49

10 En Le jardin des jeunes âmes, por ejemplo, había escrito el propio Mendès: "Je ne sais en quel temps, dans un pays dont in me m'a point dit le nom...". Cf. Marasso, 1973: 41 y ss.

11 El campo semántico parnasiano fue caracterizado por J. Lemaître como una serie de "mots d'apothéose", orientadas principalmente al cromatismo y a la sensorialidad, cuyo empleo por parte de Gautier, Banville y Rubén Darío ha sido cotejado por críticos como Erwin K. Mapes, 1952: 88 y ss. Por su parte, Marasso, 1973: 38 , nos indicaba como posible antecedente del "tacón rojo, lindo y leve el pie" -"Era un aire suave"- la frase de Gautier "el pie pequeño en el zapato de tacones rojos", del relato Avatar.

12 Tema, tono, versificación, recursos léxicos y gramaticales..., todo en "Divagación" sugiere la lectura del poema de Catulle Mendès "Le marché de la Madeleine" -Philoméla (1863)-, cuyas primeras estrofas transcribimos: "Debout! le soleil caresse nos draps. / Que ne suis-je né près de Mytilène! / Allons respirer l'odeur des cédrats / Au marché qu'on tient à la Madeleine. // J'ai rêvé d'un grand château dans la plaine. / Nous étions (hélas! tu me comprendras!) / Moi, l'hôte d'un soir, vous, la châtelaine. / Debout! le soleil caresse nos draps. // Nous voyagerons lorsque tu voudras! / Nous irons en Grèce, au pays d'Hélène / Dont les bras étaient moins beaux que tes bras. / Que ne suis-je né près de Mytilène! // En Chine où les tours sont de porcelaine, / Dans l'Inde où la noire a sous le madras / Des cheveux crépus comme de la laine, / Allons respirer l'odeur des cédrats...".

13 Sobre la presencia de Rostand en España, $c f$. Díez-Canedo, 1913: 135. Allí, el eximio crítico español sitúa la poesía de Rostand en la órbita del parnasianismo, comparándola con la de Mendès y Banville. 
fuentes posibles y probables, la metaliteratura, el despliegue culturalista y, en fin, el palimpsesto finisecular que son las Prosas profanas no restan un ápice a la originalidad y grandeza de Rubén Darío como poeta, algo que debe tenerse siempre presente. Esto no quita, sin embargo, que deba renunciarse a un sondeo de los variados estratos previos que acumula su creación poética. Y si hablamos del más influyente poemario modernista escrito en lengua española, dicho sondeo cobra aún mayor sentido: dados sus discípulos, imitadores y epígonos a lo largo y ancho del Modernismo hispánico, señalar la recepción, asimilación y adaptación del parnasianismo llevadas a cabo por Rubén Darío conlleva directa e indirectamente su extrapolación a toda una época de nuestra literatura. Partiendo de estos presupuestos, nada se interpone a la conveniencia de analizar, en la medida de lo posible, las fuentes parnasianas de poemas tan difundidos, casi diríamos fundacionales de toda una estética, como "Blasón" o "El cisne". En ambos, Rubén Darío prefigura un arquetipo de belleza aristocrática cuyos perfil y simbología presiden, desde entonces, todo el bestiario modernista. En el contexto finisecular, el cisne enlaza al espíritu pagano el wagnerianismo germánico, acaparando en sí una suma de connotaciones culturales y simbólicas que lo hacían eminentemente atractivo a los poetas, y que en su momento los parnasianos supieron idear y cultivar. El cisne parnasiano, origen de los primeros cisnes de Darío, conjuga belleza formal y trascendente, asumiendo la encarnación de su ideal poético: "En la forma de un brazo de lira / y del asa de un ánfora griega / es tu cándido cuello que inspira / como prora ideal que navega", se dice en "Blasón". Contraviniendo los principales postulados simbolistas de Mallarmé, Darío no sólo nombra el objeto, el cisne, sino que además revela expresamente cuál es su sentido racional: "rimador de ideal florilegio" -en "Blasón"-, "nueva Poesía" -en "El Cisne"-, imagen concreta de la pura Belleza abstracta y de su materialización artística más elevada, el verso. En este punto, Darío no sobrepasa los límites de la alegoría tal como Baudelaire y los parnasianos la practicaron, una alegoría "artificial y extrínseca" frente a la "natural e intrínseca" del simbolismo, Maeterlinck dixit (en González, 2000: 47) ${ }^{14}$.

Otro poema de Prosas profanas escrito bajo el palio del Parnasse fue "Del campo", según vuelve a confesarnos el poeta en Historia de mis libros: "me amparaba la sombra de Banville, en un tema y en una atmósfera criollos". En efecto, sus arriesgadas rimas agudas -"Pierrot : do-re-mi-fa-sol"-, la inclusión de

14 La genealogía del cisne parnasiano comienza con Leconte de Lisle en su poema dramático "Hélène" -Poèmes antiques (1852)-. Aquel "Cygne éblouissant qui flotte sur les eaux" de Leconte es, al igual que "El cisne" del soneto dariano, un ser de estirpe sagrada emparentado directamente con Helena y, por ello, custodio de los atributos de la belleza eterna. Tras "Le Cygne" de Baudelaire, símbolo del aislamiento del artista en un medio hostil, del que Darío nada toma, Léon Dierx retoma en "Les Cygnes" -Poèmes et poésies (1864)- el canto a su elegancia y a su Hermosura inmortal, "comme un reste orgueilleux de gloire immaculée". Por último, cabe destacar el célebre "Le Cygne" de Sully-Prudhomme -Les Solitudes, 1869-, acuarela puramente descriptiva cuya imagen final fue profusamente imitada por los poetas de su tiempo: "L'oiseau, dans le lac sombre où sous lui se reflète / La splendeur d'une nuit lactée et violette, / Comme un vase d'argent parmi des diamants, / Dort, la tête sous l'aile, entre deux firmaments.". Los motivos wagnerianos de "El cisne" de Darío, por su parte, estaban ya presentes en los Poèmes barbares de Leconte de Lisle, tal "el martillo del viejo Thor germano" o "la espada de Argantir". Rubén conjuga ambas influencias, si bien a Wagner no tendrá acceso hasta su llegada a Argentina: "En Buenos Aires, e iniciado en los secretos wagnerianos por un músico y escritor belga, M. Charles del Gouffre, rimé el soneto de El Cisne...", confiesa en Historia de mis libros (1913). En esta época de aprendiz de wagneriano compuso también el díptico "Wagneriana" -"Lohengrín" y "Parsifal"-, que no llegó a incluir en Prosas profanas. 
vocablos extranjeros -sport, sportwoman-, el guiño a personas del círculo del poeta -Andrade, Guido, Santos Vega-, o la presencia de personajes shakespeareianos y de la Commedia dell'Arte -Pierrot, Puck, Oberon, Titania...- son procedimientos que remiten directamente a las Odes funambulesques y al conjunto de la poesía banvillesca, amén de su tono festivo ${ }^{15}$. Influencia semejante caracteriza a los poemas que Darío, con acertado criterio, ordena a continuación. Así, en "Alaba los ojos negros de julia", y tal como ya hiciese Banville en Les Princesses, prefigura el eterno ideal femenino mediante la evocación de figuras de la Mitología y la Historia como Pentesilea, Judith o Cleopatra. La imitada "Canción de carnaval", por su parte, ábrese con la trascripción de los dos primeros versos de "Mascarades" -Odes funambulesques-: "Le carnaval s'amuse! / Viens le chanter, ma muse". Darío, que una vez más en Historia de mis libros admite haber escrito este poema "a lo Banville, una oda funambulesca de sabor argentino", recrea con buen saber hacer una de las formas predilectas del poeta francés, la "odelette" u "odita", según el propio nicaragüense había subtitulado ya algunas composiciones anteriores muy similares como "Los regalos de Puck. Versos de año nuevo". Reencontramos aquí a los personajes de la Commedia dell'Arte pirueteando en medio del carnaval, hilvanando con sus apariciones y desapariciones una rima y otra: "Mientras Arlequín revela / que al prisma sus tintes roba / y aparece Pulchinela / con su joroba, // di a Colombina la bella / lo que de ella pienso yo, / y descorcha una botella / para Pierrot..."" . Paralelamente a la "odelette", también el sonetillo de arte menor y tema galante, adoptado por Rubén en el díptico "Para una cubana" y "Para la misma", sigue a rajatabla el esquema banvillesco, mientras que otro madrigal galante, en este caso el dodecasilábico "Bouquet", declara su parentesco con Gautier: "Un poeta egregio del país de Francia, / que con versos áureos alabó el amor, / formó un ramo armónico, lleno de elegancia, / en su Sinfonía en Blanco Mayor...". "Bouquet" imita, además, el desarrollo plástico de la aludida sinfonía gauteriana, en cuya blanca monocromía irrumpe, finalmente, el fuerte contraste del rojo: "Yo, al enviarte versos, de mi vida arranco / la flor que te ofrezco, blanco serafín. / ¡Mira cómo mancha tu corpiño blanco / la más roja rosa que hay en mi jardín!".

Hasta aquí, todo en Prosas profanas se ciñe al ascendiente parnasiano, si bien a continuación Darío incluye una serie de composiciones escritas a la sombra del decadentismo y del simbolismo como "El faisán", "Garçonnière", "Margarita", "Mía", "Dice mía", "Heraldos" e "Ite, missa est". Pronto, sin embargo, retoma Rubén el viejo camino, y a la luz del Parnasse contemporain concluye esta primera sección, intitulada de manera homónima, "Prosas profanas", con "El país del sol" y uno de sus poemas más celebrados, el "Coloquio de los centauros". "El país del sol" ensaya en español el poema en prosa parnasiano, ciñéndose de nuevo al modelo de Catulle Mendès, según nos confiesa el poeta, esta vez en su

15 Por su amenidad, frescura y jovialidad, la poesía banvillesca será siempre celebrada por Darío. Entre los nombres que integran el soneto "A los poetas risueños" - $2^{a}$ edición de Prosas profanas (1901)- no dudará nuestro poeta en ensalzar a "Banville, insigne orfeo de la sacra Harmonía".

16 No está de más recordar que, en el círculo parnasiano, hubo otros poetas como Catulle Mendès que gustaron también de los motivos de la Commedia dell'Arte: "Le nez de Pierrot" -La Grive des vignes-, "Pierrot faché à cause de la lune" o "Puck tout nu" -Poésies nouvelles- son muestras singulares de ello, si bien Darío invoca en todo momento a Banville, nunca a Mendès, a este respecto. 
Autobiografia: "de fecha muy anterior a las poesías escritas en Buenos Aires, [está] calcado en ciertos preciosos y armoniosos juegos que Catulle Mendès publicó con el título de Lieds de France". Se trata, en efecto, de una prosa ritmada y rimada cuya severa formalización, basada en los efectos musicales de brevedad, recurrencia y simetría, la cadencia regular del fraseo, la división estrófica y la repetición de un estribillo, dotaba al poema de una homogeneidad y circularidad más acordes con las teorías métricas del Parnaso que con la prosa flexible, sin ritmo y sin rima, ideal para adaptarse a los "mouvements lyriques de l'âme, aux ondulations de la rêverie, aux soubresauts de la conscience" de Baudelaire y los simbolistas ${ }^{17}$.

Mayores controversias ha suscitado, en cuantos a sus fuentes e interpretación, el "Coloquio de los centauros", poema de hondas resonancias filosóficas. No era la primera vez que Darío abordaba el motivo centáurico en su poesía, pues ya en la Revista de Costa Rica -marzo de 1892- había publicado "Los Centauros (Bajo relieve)", luego rebautizado "Palimpsesto" e incluido en estas Prosas profanas. Sin embargo, y frente a la pura ornamentación del poema escrito en Centroamérica, el "Coloquio de los centauros" incorpora a la poesía de Darío un componente metafísico que ha hecho correr ríos de tinta, no siempre en beneficio de una exégesis cabal.

Si nos atenemos, en primer lugar, a un nivel estrictamente formal, el poema presenta una disposición versal en extensas tiradas de alejandrinos geminados con rima consonante; una estructura métrica clásica que el Parnaso había juzgado la más óptima para configurar poemas dramatizados de la misma naturaleza que el de Darío. Sólo en los Poèmes antiques de Leconte de Lisle pueden contabilizarse bastantes ejemplos de diálogos líricos elaborados preferentemente con dicha versificación, tales "Bhagavat", "Çunacépa", "Hélène", "Niobé", "Khirôn" o "Hypatie et Cyrille". Obviando, evidentemente, su devenir histórico desde Platón, el poema dialogado de cariz expositivo en el que se abordan variados fundamentos filosóficos tuvo grandes cultivadores entre los parnasianos, así el propio Leconte de Lisle o su maestro en este campo, Louis Ménard. Un poema de éste último como "Le Banquet d'Alexandrie" -Poèmes et rêveries d'un païen mistique- presenta ciertos puntos de contacto con el poema de Darío nada desdeñables. Se trata de un diálogo entre los discípulos del filósofo de Alejandría Ammonius Saccas (siglos II y III d. C.), fundador de la escuela neoplatónica, en el que salen a la palestra temas que luego abarcaría también Rubén en su poema como el de la mujer, el mal o la muerte. Aunque el tono elegante y cívico del diálogo de Ménard sea muy similar al que emplea el nicaragüense, bien es cierto que el asunto principal de "Le Banquet d'Alexandrie", la religión, no llega a ser abordado en el "Coloquio de los centauros". Por otra parte, el excesivo didactismo y una cierta aridez en la factura del verso en Ménard son trocados en Darío por la gracia y el sentido musical del modernista, más poeta que erudito. $\mathrm{Y}$ en cuanto a los personajes y al marco ambiental, Rubén sustituye a los filósofos históricos y a su academia por seres

$17 C f$. Baudelaire, “À Arsène Houssaye", Petits poèmes en prose. Recordemos un par de estrofas de "Les pieds nus" -Lieds de France- de Mendès para ilustrar la prosa parnasiana que Darío imita rotundamente en "El país del sol!": "Sans bas, cuir, ni semelle (Vive ma belle!) et sans sabots, je marche depuis l'aube neuve (Marche, vagabond, le jour est si beau!) sur l'âpre terre du talus, sur l'âpre terreo où le blé lève... Le terre aime les pieds nus!". 
mitológicos que se solazan en el Elíseo, pura geografía poética, una "isla de oro" cuyo tiempo y espacio son irreales. A pesar de todo, la interpretación simbólica del mundo en ambos poemas no deja de guardar claras analogías, por más que un sector de la crítica haya querido, precisamente por este trascendentalismo, negar la adscripción del "Coloquio de los centauros" a la poética parnasiana ${ }^{18}$.

Teniendo en cuenta la condición poligenética de la poesía de Rubén Darío, y en particular, de este "Coloquio de los centauros", no resulta tarea baladí el remontarse a sus fuentes directas. Ya Paul Groussac (1916: 43), a quien precisamente va dirigida la composición, avisaba sobre esta dificultad, dada la intensa reelaboración de ascendencias poéticas variadas que Darío llevaba a cabo en su proceso creativo. Pese a ello, son varios los estudiosos de la obra dariana como María Teresa Maiorana (1959), Marie-Josèphe Faurie (1966), Arturo Marasso (1973) o Margareta Dolinescu (1984) que, aceptando el reto, nos han dejado interesantes reflexiones, cuando no conclusiones definitivas, en esta dirección. Dentro de la superabundancia de antecedentes de los que se valió Darío en la elaboración de su poema, conviene señalar, en primer lugar, sus reminiscencias textuales con Le centaure de Maurice de Guérin (1836) y con "Khirôn" -Poèmes antiques- de Leconte de Lisle, quien, a su vez, partía del propio Guérin y de otros textos como "Le Centaure" de Alphonse Rabbe (1835). Todos estos textos tienen en común con el poema dariano ciertos pasajes donde se celebra la juventud fogosa del centauro, su fuerza y velocidad, fluyentes como un gran río desbordado, así como su capacidad sensitiva, afinada en el ritmo vital de la naturaleza y el universo ${ }^{19}$. La actitud del personaje central, Quirón, varía sin embargo en los citados autores: el "Macarée" de Guérin es un centauro modesto que encomia la paz de una vida hacendosa; el "Khirôn" de Leconte de Lisle es altivo y se rebela contra los dioses del Olimpo, lo cual le costará la vida; mientras que el "Quirón" dariano encarna el optimismo, la armonía del arte y el triunfo de la eterna poesía. No hay que insistir demasiado, por otra parte, en las diferencias gráficas de los nombres propios: Darío simplemente latiniza el griego de Leconte de Lisle, prefiriendo las formas empleadas por Ovidio en Metamorfosis, aunque bien es verdad que a veces alterna unas y otras -"Heracles" y "Hércules"-. En cuanto al componente plástico del poema, fueron los grabados integrados por René Ménard, hermano de Louis, en La Mythologie dans l'Art ancien et moderne (1878) los que sirvieron de punto de partida a Darío, quien manejó durante muchos años un ejemplar de dicha obra. Las estrofas del Coloquio centradas en la escena del

18 En este sentido, ya un crítico como Arturo Marasso (1973: 67) había llamado la atención del fondo filosófico que subyace a la poesía del parnasiano Louis Ménard y sus concomitancias con la poesía dariana: "[Ménard] le enseñó a descubrir el símbolo, sin el cual [...] las representaciones parnasianas no serían sino una obra de orfebre, de burilador o de estatuario [...]. Como maestro oculto y aun ocultado de Leconte de Lisle, de Heredia, en lo que ellos no hubieran alcanzado solos, dio al parnasianismo, aunque de paso, cierta iniciación en los misterios".

19 Pueden compararse, por ejemplo, los siguientes párrafos de Leconte de Lisle y Darío en que se describen dichas condiciones: "Oui! j'étais jeune et fort; rien ne bornait mes voeux: / J'étreignais l'univers entre mes bras nerveux; / L'horizon sans limite aiguillonnait ma course, / Et j'étais comme un fleuve égaré de sa source, / Qui, du sommet des monts soudain précipité, / Flot sur flot s'amoncelle et roule avec fierté..." ("Khirôn", Poèmes antiques); "Son los Centauros. Unos enormes, rudos; otros / alegres y saltantes como jóvenes potros; / unos con largas barbas como los padres-ríos; / otros imberbes, ágiles y de piafantes bríos, / y robustos músculos, brazos y lomos aptos / para portar las ninfas rosadas en los raptos." ("Coloquio de los centauros", Prosas profanas). 
nacimiento de Venus arraigan, además, en una larga tradición pictórica y literaria que parte de la antigüedad grecolatina -Apeles u Homero-, pasando por el renacimiento -Boticelli, Tiziano- y el neoclasicismo -Boucher- hasta desembocar en pleno siglo XIX -Ingres- y en el Parnasse contemporain, cuyos autores principales la recrearon en sus obras: Leconte de Lisle en "Khirôn" -versos 331 a 340- o José María de Heredia en Les Trophées -"La Naissance d'Aphrodite"-. En cualquier caso, la pintura de Darío no guarda semejanzas destacables con ninguna de las obras aludidas, tratándose de una visión más personal del mito.

El "Coloquio de los centauros" trasciende lo meramente plástico y dramático en aras de una mayor intencionalidad alegórica. A Hugo, a Nerval, a Baudelaire, a Ménard, al Gautier de "Affinités secrètes" saben ciertos pasajes en los que asoma una ontología romántico-simbólica, trascendental, con ciertos ribetes esotéricos incluso (Cf. Marini-Palmieri, 1989: 83-91). Canta Quirón, y su canto pánico restituye la unidad entre lo material y lo espiritual, canta el alma de las cosas, canta la dimensión metafísica de lo sensible: “ ¡Himnos! Las cosas tienen un ser vital; las cosas / tienen raros aspectos, miradas misteriosas; / toda forma es un gesto, una cifra, un enigma; / en cada átomo existe un incógnito estigma...”. A ojos de QuirónDarío, existe una unidad suprema en la que todos los elementos de la naturaleza se corresponden: "Ni la torcaz es benigna / ni es el cuervo protervo: Son formas del Enigma / la paloma y el cuervo". El fragmento del coloquio en que se discute sobre la mujer, tema que desarrolla magistralmente Heredia en "Centauros y Lapitas", "La Centauresse" o "Nessus", opone los principios masculino y femenino para entonar, a manera de conclusión, un himno al ser hermafrodita -"Cinis será Ceneo"-, tal como Théophile Gautier había hecho en "Contralto"-Émaux et camées-. Lo ético y lo estético participan de una misma esencia, de una misma noesis que, sin obliterar la originalidad y competencia del poeta nicaragüense, era común a muchos de los grandes autores del romanticismo y del Parnaso. El último de los problemas abordados por el coloquio es el de la muerte, y a este respecto, la conclusión de Darío recuerda de nuevo a Louis Ménard: si Quirón afirma que "La muerte es la victoria de la progenie humana" y que "La pena de los dioses es no alcanzar la muerte", Louis Ménard cierra su soneto "Stoïcisme" -Poèmes et rêveries d'un païen mistique- con palabras muy similares: "Sans rien leur envier, car lui, pour la justice / Il offre librement sa vie en sacrifice, / Tandis qu'un dieu ne peut ni souffrir ni mourir".

En mi opinión, el "Coloquio de los centauros" no participa de la poética del simbolismo, no se sustenta en sugerencias musicales ni herméticas asociaciones de sentido, en obsesivas acumulaciones de imágenes ni siquiera en complicación gramatical ninguna para evocar un estado de alma, a la manera de "Hérodiade" o "L'après-midi d'un faune" de Mallarmé. Su desarrollo alegórico, en el que hay "más arquitectura y escultura que música, más cincel que cuerda y flauta", según el propio Darío aceptaba en Historia de mis libros, lo convierte en una muestra, soberbia, única, inmortal muestra del mejor parnasianismo, el más agudo y penetrante, el más desatendido tradicionalmente por la crítica.

La segunda sección de Prosas profanas, "Varia", comprende una serie de poemas de diversa naturaleza: "El poeta pregunta por Stella" -cuyo título recuerda a aquellos que Catulle Mendès gustaba poner a sus versos, tal "Le poète s'interrogue", "Le poète se souvient", "Le poète ne se plaint"...-, "La página 
blanca", "Año nuevo", "La Dea" y "Epitalamio bárbaro" recuperan los ecos simbolistas y decadentes; mientras que "Pórtico", "Elogio de la seguidilla" y la "Sinfonía en gris mayor" permanecen más cercanos a los dogmas parnasianos ${ }^{20}$. Por su parte, la tercera sección, "Verlaine", consta del célebre "Responso" y de "Canto de sangre", poemas de inspiración verlainiana, mientras que la cuarta, "Recreaciones arqueológicas" -"Friso" y "Palimpsesto"- engarza de nuevo con lo más parnasiano de las Prosas profanas ${ }^{21}$. Finalmente, la obra se cierra con "El reino interior", dedicado a Eugénio de Castro y escrito a la manera del simbolista portugués.

Parnasianismo, decadentismo, simbolismo, modernismo en definitiva, las Prosas profanas conjugan múltiples corrientes poéticas que, como el aceite en el agua, no terminan de desleírse, íntegramente, en una sola. Más allá de la mera diferencia cronológica entre la composición de unos poemas y otros, cuyo peso al respecto es innegable, asistimos a una pluralidad congénita a su expresión lírica que nos deja en el libro poemas parnasianos y poemas que no lo son, por más que todos lleven la misma firma de autor. A propósito de $A z u l . .$. , y a propósito de Prosas profanas, la balanza se inclina, manifiestamente, del lado del Parnasse. Así lo vieron, amén del propio Rubén, sus primeros lectores de renombre como Paul Groussac, Enrique Gómez Carrillo o José Enrique Rodó ${ }^{22}$.

20 A pesar de que Darío, de nuevo en Historia de mis libros, afirma que su Sinfonía en gris mayor "trae necesariamente el recuerdo del mágico Théo, del exquisito Gautier", no es menos cierto que su desarrollo cromático, contrariamente al de "Bouquet", se aleja del modelo gauteriano en una serie de puntos. A. M. Diaconescu (1974: 791-810) ha analizado concienzudamente el poema, comparándolo además con el célebre "Les éléphants" de Leconte de Lisle, y señala con acierto que si en su estructura externa ambos poemas coinciden plenamente, y que las técnicas de composición de Darío son análogamente parnasianas, el nicaragüense introduce por su parte algunos elementos de raigambre simbolista -vaguedad del color gris, ambiente crepuscular, sugerencias musicales- que se corresponden con el estado anímico del yo lírico. Obviando las de Darío, el poema de Gautier vio múltiples imitaciones en la literatura finisecular, desde la "Symphony in yellow" de Oscar Wilde a la "Symphonie en gris" de Marie Krysinska, una proliferación de sinfonías cromáticas que llevó al colombiano José Asunción Silva a componer su burlesca "Sinfonía color de fresa con leche".

21 "Friso" presenta una descripción ecfrástica de motivos helenísticos cuya versificación y lenguaje endecasílabos blancos abundantes en giros intencionadamente arcaizantes- imita tanto las traducciones decimonónicas de poesía griega clásica como la lírica academicista de los Juan Valera y Menéndez Pelayo en España o de Guido Spano en la propia Argentina. El propio Darío lo recordaba en Historia de mis libros, admitiendo que en "Friso" "recurro al elegante verso libre, cuya última realización plausible en España es la célebre Epístola a Horacio de Don Marcelino Menéndez y Pelayo". De "Palimpsesto" ya adelantamos más arriba que había aparecido en 1892 con el título de "Los centauros (Bajo relieve)". Recreación plástica de la escena de Diana en el baño y del rapto de una de sus ninfas por un centauro, fue escrito en el momento en el que Darío sentía mayor veneración por José María de Heredia, y a ello se deben sin duda las reminiscencias de algunos sonetos de Les Trophées como "La Centauresse" o "Le Bain des Nymphes" que cruzan los versos darianos.

22 Desde las páginas de La Biblioteca, Groussac (1897: 62 y ss) consideraba la obra toda ella imitación de lo francés, desestimando cuanto allí había de decadente: "El señor Darío es muy joven; sobrevivirá sin duda al movimiento perecedero y fugaz a que se ha adherido...". En su fuero conservador, Groussac juzgaba la parnasiana aquella tendencia que contenía lo más válido y en sí "poético" del libro, "la cincelada orfebrería de las palabras, nombres, verbos y adjetivos de elección, que se engastan en la trama del verso como gemas en filigrana". De signo contrario fueron las primeras impresiones de Gómez Carrillo (1900: 54), decepcionado ante el parnasianismo, ya trasnochado en su opinión, de Rubén. Con hiriente ironía y un aire condescendiente que imaginamos humillaron al gran poeta, el crítico guatemalteco, desde la soberbia de sus hábitos parisinos, juzga los nuevos partos de Rubén una sarta de ingenuidades fuera de temporada, ajenas al devenir más actual de la poesía francesa: "Su Azul... de usted no es todo azul; sus Prosas profanas no son prosas; y sus Raros tampoco son raros. No, Rubén, no lo son, o por lo menos, no lo son en Europa en este año de 1898. ¿Leconte de Lisle raro? [...] Casi tanto como Zola y Dumas...”. En cuanto a Rodó (1899, en 1924: 129), la poesía 
Durante sus años en Buenos Aires, y hasta su partida definitiva a Europa en 1898, la poesía de Darío se incardina en un modernismo de raigambre francesa cuyos constituyentes fundamentales fueron decadentes, simbolistas y, por encima de todo, parnasianos. Varios son los poemas que Darío no incorporó a Prosas profanas, si bien podría haberlo hecho con facilidad, que participan de una poética aprendida en los libros de Verlaine, Régnier o Moréas - "Florentina", "Como palomas tórnanse los tigres de la Hircania"...-, y más aún los que beben de Gautier, Banville o Mendès -"Porteña", "Flor argentina", "Mima. Elegía pagana", "Toast" o la funambulesca "Frank Brown"-. Cuesta imaginar a Rubén Darío en Europa, más allá del año 1898, componiendo poemas de esta hechura. Así lo corrobora, por otra parte, una lectura cronológica y atenta a toda su poesía completa, tanto si fue editada en revistas y poemarios como si ha permanecido en una esfera mucho menos divulgada. 1898, con todo lo que esta fecha significa, cierra una etapa en la trayectoria literaria y vital de Rubén Darío cuyo efecto sobre la propia poesía hispánica es irrecusable. Rumbo a los Cantos de vida y esperanza y a un modernismo de otra naturaleza, y más allá de valoraciones subjetivas, Rubén se deja para siempre en Buenos Aires un algo de sí, lo más parnasiano, por mucho que su fidelidad para con los maestros franceses nunca se apagase del todo.

\section{Rubén Darío en Europa (1898-1916)}

En el otoño de 1898, Rubén se embarcaba hacia España como corresponsal de $L a$ Nación para cubrir con sus crónicas la información sobre el estado de nuestro país tras el Desastre en Cuba, y en diciembre pisa por segunda vez tierra española. En un principio, el panorama literario que aquí halló no pudo resultarle más desalentador: hasta su viejo amigo Salvador Rueda, con quien había compartido aquellos días parnasianos de 1892, abjuraba de modernismos, vuelto ahora al redil de los campoamorianos, los núñezarcianos, los endecasilabistas. Así lo daba a entender en sus lúcidas crónicas enviadas puntualmente a La Nación entre diciembre de 1898 y abril de 1900, luego recogidas en el volumen España contemporánea (1901).

Pese a evocar en ciertas ocasiones el exotismo colorista del Gautier de Voyage en Espagne ${ }^{23}$, Rubén contempla con ojos sinceros la realidad nacional, especialmente la literaria, cercada de tradicionalismo, anquilosada, amurallada ante

\footnotetext{
dariana se le antojaba una legítima actualización en lengua española del elitismo lírico de los parnasianos y simbolistas franceses, si bien enlazaba principalemente con el parnasianismo sensual y vitalista de los Gautier y Banville, antes que con las sombras de Baudelaire y Verlaine. Otro crítico de no menor valía como el español Enrique Díez-Canedo (1916: 54) defendía, poco después de la muerte de Darío, una postura muy semejante respecto a las fuentes de Prosas profanas: "no debe tanto como se ha dicho a Verlaine y nada a Mallarmé. Mucho, en cambio, a Banville, a Gautier, al mismo Catulle Mendés [...]. En resumen, sus maestros franceses, más hay que buscarlos entre los parnasianos que entre los simbolistas...”.

23 A propósito de aquella España romántica y pintoresca de Gautier, Darío se quejaría en Tierras solares (1904) de su desaparición: "El progreso es el enemigo de lo pintoresco, y su nivelación no va dejando carácter local ni originalidad en ninguna parte. Hay andaluces de la hora presente que protestan contra la Andalucía de figuras de pandereta y caja-de-pasas, que tanto ha dado que escribir, cantar y pintar, la Andalucía byroniana, de Gautier, la de D'Amicis; protestan porque quieren otra Andalucía semejante a los Dorados comerciales en que piensa mi amigo Maeztu. ¡A Ah! desgraciadamente ya no encontramos la poética Andalucía sino muy venida a menos o muy ida a más. [...] Gautier y D'Amicis llegaron a estas tierras en tiempos mejores...”.
} 
las novedades extranjeras: "todo lo que no sea en metros usuales, silva, seguidilla, romance, sería mal visto, y renovadores de métrica como Banville, Eugenio de Castro o D'Annunzio, correrían la suerte del buen Salvador Rueda", comunica en la crónica "Cyrano en casa de Lope" del 2 de febrero de 1899. Desde su punto de vista, algo fatalista y extremado, en Madrid, y en comparación con Buenos Aires, resultaba tarea imposible encontrar un libro extranjero: "París está a un paso y me ha sucedido leer en La Nación el juicio de un libro francés antes de que ese libro hubiese llegado a Madrid. El que no encarga sus libros a Francia, Inglaterra, etc., no puede estar al tanto de la vida mental europea" ("Libreros y editores", 14 de julio de 1899). Una de las crónicas de mayor relevancia en este sentido, "El modernismo", del 28 de noviembre de 1899, enjuicia la penosa situación de la nueva estética en España y las posibles causas de ello. Para Darío, y en este punto hemos de concederle cierto asentimiento, en España se atacaba continuamente al modernismo sin que éste asomara por ninguna parte: "se habla de decadentes, de estetas, de prerrafaelistas con $s$, y todo. Es cosa que me ha llamado la atención no encontrar desde luego el menor motivo para invectivas o elogios, o alusiones que a tales asuntos se refieran". El "formalismo tradicional", "la concepción de una moral y una estética especiales" y, sobre todo, el "españolismo" impedían cualquier atisbo de renovación, eso sin olvidar la pésima calidad y poca profesionalidad de nuestra crítica literaria. A todo ello debe sumarse "la poca difusión de los idiomas extranjeros, la ninguna atención que por lo general dedica la prensa a las manifestaciones de vida mental de otras naciones, [...] y después de todo, el imperio de la pereza y de la burla".

Muchas cosas, por lo tanto, parecen no haber cambiado desde su primera estancia en España, allá por 1892. Otras sí, entre ellas, fundamentalmente, el propio Rubén Darío. Ya no estamos ante el joven que celebraba la gracia española con los versos puramente parnasianos de aquella "Canción de España": "Existe en el salón de porcelana / del Palacio Real una Diana / labrada en alabastro. Es blanca y bella. / La divina doncella / decora el borde fino de una mesa....". Los trágicos sucesos del 98 han revitalizado en él una conciencia panhispánica que no habrá de abandonarle ya hasta el fin de sus días. Ahora canta su llegada a nuestro país con un soneto como "España", en el que se evidencia el rumbo que va tomando la lírica del nicaragüense y que desembocará en los magistrales Cantos de vida y esperanza: "Dejad que siga y bogue la galera / bajo la tempestad, sobre las olas: / va con rumbo a una Atlántida española, / en donde el porvenir calla y espera...".

Durante su segunda etapa en España, Darío se reencontró con lo más selecto de las letras patrias, aquellos autores que ya tratara en el 92 y que vivían sus últimos días de decadencia vital y literaria: Campoamor, Castelar, Valera, Núñez de Arce. Pero si por entonces sólo estuvo Salvador Rueda para comprenderle, con el paso de los meses Darío poco a poco irá encontrando, en el Madrid de principios de siglo, una legión de escritores de talante radicalmente innovador que comienza a destacarse del marasmo general: son los Benavente, Unamuno, Baroja, Maeztu, los Machado, Villaespesa o J. R. Jiménez quienes habrán de acogerle, cada cual según su talante, como al profeta que de allende los mares viene a traer la buena nueva del modernismo. Darío, sin recelo alguno y dejándose llevar por el entusiasmo hacia las novedades del que siempre hizo gala, les augura un porvenir dorado. Para un jovencísimo Juan Ramón Jiménez escribe, ya desde París, el célebre "Atrio" que 
abrirá sus Ninfeas y en el que le impele a luchar por el arte nuevo - ¿ ¿Tienes, joven amigo, ceñida la coraza / para empezar, valiente, la divina pelea?..."-, un arte nuevo naturalizado en un simbolismo trascendental: " ¿Tu corazón las voces ocultas interpreta?".

Darío arriba por segunda vez a París en abril de 1900, enviado por La Nación para cubrir la información sobre la Exposición Universal. Allí se relaciona de nuevo con Enrique Gómez Carrillo y con otros modernistas hispanoamericanos como el mexicano Amado Nervo, amén de dar a la estampa la segunda edición de sus Prosas profanas (1901). A grandes rasgos, las nuevas Prosas profanas mantienen la estructura de la edición princeps, salvo por algunas adiciones finales que en cierta medida rompen la unidad del libro original. Son poemas que denotan la madurez alcanzada por Darío en su búsqueda de una poesía humanitaria e hispánica, menos adepta a parnasianismos y artificiosos decadentismos y cuyo tono resuena más cercano a los inminentes Cantos de vida y esperanza que a las propias Prosas profanas de 1896. Estas nuevas adiciones comienzan en "Cosas del Cid", recreación de una composición de Barbey d'Aurevilly, a la que sigue la sección "Dezires, Layes y Canciones", cuyo primitivismo, que imita la lírica medieval de Johan de Duenyas o Johan de Torres, participa de la moda impuesta por decadentes y prerrafaelitas ${ }^{24}$. El libro concluye con una última sección de fisonomía variada, "Las ánforas de Epicuro". Exceptuando una "Marina" de construcción libre, en la que Darío no dejaba de recordar a sus maestros predilectos -"Mi barca era la misma que condujo a Gautier / y que Verlaine un día para Chipre fletó"-; pese a dos sonetos de factura parnasiana como "A Maestre Gonzalo de Berceo" y "La gitanilla"; y más allá de la alusión a "Banville, insigne orfeo de la sacra Harmonía" en la pieza "A los poetas risueños", "Las ánforas de Epicuro" presenta una serie de sonetos de inspiración filosófica, algunos tan sustanciales como "Ama tu ritmo..." o "Yo persigo una forma...". Según el propio poeta expresase en Historia de mis libros, los sonetos de "Las ánforas de Epicuro" participan de una "exposición de ideas filosóficas" tales "la concentración de un ideal religioso a través de la Naturaleza", "la exaltación de la personalidad", "la conjunción de las exaltaciones pánica y apolínea", "la exposición de la potencia íntima e individual", "el arcano de tristezas autumnales", "la concreción espiritual de la metamorfosis" y otras alegorías de raigambre pitagórica y esotérica que tendían puentes espirituales entre el modernismo, el simbolismo y el romanticismo primigenio ${ }^{25}$.

En septiembre de 1901 Darío viaja por Italia, y tras pasar el invierno en París, lo tendremos en la primavera y el verano de 1902 visitando Londres, Bruselas, Brujas y Dunkerque. Ese año se publicaron sus Peregrinaciones, donde recogía sus crónicas sobre la Exposición Universal, los apuntes de su viaje a Italia y varios ensayos literarios y artísticos dedicados a figuras como Oscar Wilde o Rodin. En el

24 No debe olvidarse por ello que una de las mayores preocupaciones de un parnasiano como Banville fue la de resucitar antiguas formas poéticas medievales de estructura fija como el triolet, la balada, el rondel o el “dizain”, y que en su Petit traité de poèsie française dedicó un buen número de páginas a analizarlas y a proponer su imitación.

25 El pitagorismo romántico propio de los Vers dorés de Gérard de Nerval, sumado a las “Correspondencias” y a la analogía universal de Baudelaire le sugieren a Tomás Segovia (2004: 1089) las fuentes del pitagorismo rubendariano en "Las ánforas de Epicuro", expresado fundamentalmente en "Palabras de la satiresa" y "Ama tu ritmo...". 
texto dedicado a éste último, el poeta confesaba abiertamente cuáles eran las directrices que por entonces regían su concepción poética, tan diferentes ya de aquellas que perfilara en las notas a la segunda edición de Azul...: "Quería oír la voz misteriosa de la plasmada materia, el canto de la línea, la revelación del oculto sentido de las formas. Me atrevo a decir - no sin cierto temor-, que comprendo a Mallarmé; [...] he leído a René Ghil, sacando algún provecho”. Sus patrones responden ya por entero al simbolismo, de ahí que los versos que citase a lo largo del libro a guisa de arquetipos fuesen todos de Mallarmé, de Samain o de Moréas.

En otoño de 1902 se trasladó a Barcelona, y durante el invierno recorrió Andalucía y Tánger para, tras una estancia breve en Madrid, regresar a París en marzo de 1903 con el nombramiento de cónsul de Nicaragua bajo el brazo. En mayo haría de nuevo las maletas para viajar sucesivamente por Alemania, Austria, Hungría e Italia, en un incesable deambular que habrá de recoger en las crónicas y artículos de La caravana pasa (1903) y de Tierras solares (1904). En unas páginas dedicadas en la primera obra al auge de los cancionistas parisinos, Darío lamentaba el estado de la poesía francesa, dominaba por los parnasianos menores, y cómo los maestros simbolistas iban cayendo en el olvido: "Los poetas oficiales son como Rostand o como Sully-Prudhomme... Ni unos ni otros llenan el vacío ideal. Los otros se van cada cual por su camino, mientras las sombras de Verlaine y Mallarmé desaparecen entre los cipreses obscuros de una hermosa leyenda...". Ni tan siquiera uno de los viejos ídolos parnasianos como José María de Heredia se libraría ya de algún que otro ataque del neófito simbolista. Así, en otra crónica de La caravana pasa criticaba con dureza un poema que el autor de Les Trophées dedicase a la emperatriz de Rusia: "Eran versos serios, académicos y mediocres [...]. Ante los malos versos aristocráticos, prefiramos los buenos versos anarquistas [...]. Las musas de la Cúpula no han ayudado al ilustre autor de los Trofeos...".

Desde junio de 1904 hasta febrero de 1905 Rubén permanece en París, para establecerse entre febrero y julio de 1905 de nuevo en Madrid, donde organiza con Juan Ramón Jiménez la publicación definitiva de sus Cantos de vida y esperanza, una obra que supuso la consagración definitiva del Rubén Darío poeta, la cima de su lírica y a la vez el último de sus grandes poemarios.

Los flamantes Cantos de vida y esperanza vienen marcados profundamente por el subjetivismo, la reflexión ontológica y una nueva manera de concebir la estética finisecular sin la extremada ascendencia parnasiana y decadente de épocas anteriores. Puntualizando los célebres versos que cierran " $L$ 'Art" de Gautier, Rubén confiesa en Historia de mis libros que "si es cierto que el busto sobrevive a la ciudad, no es menos cierto que lo infinito del tiempo y del espacio, el busto, como la ciudad, y, ¡ay! ¡el planeta mismo, habrán de desaparecer ante la mirada de la única Eternidad!’. Más allá del pesimismo posromántico, más allá del vitalismo pagano, polos anímicos entre los que oscilaba la poética parnasiana, Darío encarna en su crisis personal la crisis espiritual del Fin de Siglo en toda su extensión. Y para superarla, vemos al poeta recurriendo finalmente a Dios, a la "única Eternidad" que habrá de sobrevivir a todo, perdida ya la fe en aquella pureza eternal de la Belleza que Gautier preconizase: "Tout passe. — L'art robuste / Seul a l'éternité. / Le buste / Survit à la cité".

España y el hispanismo, el panlatinismo cultural, el antiimperialismo, una honda perspectiva ética enfocada en los temas universales de la religión, el 
misterio, la vida y la muerte, la tensión dialógica entre Eros y Thánatos, ¿qué espacio podía quedar para el parnasianismo en un poemario de esta naturaleza? Los cuatro o cinco poemas parnasianos presentes en Cantos de vida y esperanza rompen manifiestamente la unidad tonal del libro y, además, todos fueron escritos durante una etapa bastante anterior a la segunda estancia en España del poeta. Así, uno de los más célebres del libro y de toda la obra del nicaragüense, la excelsa "Marcha triunfal", había visto ya la luz en La Nación el 25 de mayo de 1895. De época anterior son igualmente "Ofrenda" y "A Goya": el primero, con el título de "Bouquet", estaba fechado en "Panamá, mayo de 1893", y el propio poeta, en Historia de mis libros, lo define como una "ligera y rítmica galantería banvillesca", en tanto que el segundo, de inspiración gauteriana, había sido publicado ya en el diario mexicano El Mundo el 23 de mayo de $1897^{26}$. La pieza parnasiana más ortodoxa de todas, "Leda", fue presentada en Guatemala ilustrada quince años antes, en septiembre de 1892: "El cisne en la sombra parece de nieve; / su pico es de ámbar, del alba al trasluz; / el suave crepúsculo que pasa tan breve / las cándidas alas sonrosa de luz...". Pasajes aislados hay también en Cantos de vida y esperanza que remiten al Parnaso, pese a su integración en composiciones regidas por otros impulsos e intenciones comunicativas. Valga como ejemplo el primer verso de "Canto de esperanza", "Un gran vuelo de cuervos mancha el azul celeste", que trae a la memoria un verso de "Le massacre de Mona" de Leconte de Lisle Poèmes barbares-: "Un long vol de corbeaux tourbillonait dans 1'air".

La recepción en España de Cantos de vida y esperanza fue, como se sabe, gloriosa, toda vez que el modernismo había conquistado por fin las letras de nuestro país. Baste recordar la reseña "Poetas americanos. Rubén Darío" que el 26 de junio de 1905 le dedicara en El heraldo de Madrid Manuel Bueno. Siguiendo a pies juntillas las teorías de Mallarmé y del manifiesto simbolista, Bueno oponía allí una lírica de la vaguedad y la sugerencia, moderna en puridad, a otra vieja, tallada "con escueto relieve", propia del Parnaso. La dimensión que cobra este texto radica en una doble condición paradigmática: por una parte, expresa la apreciación general que de la poesía moderna se tenía en la España de 1905; por otra, revela cuán poca distancia podía haber entre un modernista como Darío y un Manuel Bueno, autor al que se ha incluido tradicionalmente en la nómina de la denominada "Generación del 98":

En vez de describir, ¿por qué no sugerir? En vez de ir directamente a la realidad normal, ¿por qué no extraer de ella lo escondido, lo raro, lo que no se revela ni se descubre a las almas adocenadas, sino a los seres escogidos? [...] Los simbolistas -y yo tengo a Rubén Darío, a lo menos en ciertos momentos, por un Mallarmé castellano-, los simbolistas aman la alegoría y la leyenda tanto como desdeñan la realidad directa, el natural palpable, con sus anecdóticas minucias y sus normales episodios. [Darío] es un gran prestigio de las letras castellanas y un artista que puede codearse familiarmente con Verharen (sic), D'Annunzzio (sic), Laforgue,

26 Ha sido Arturo Marasso (1973: 269-270) el primero en señalar la fuente de los tercetos monorrimos de "A Goya" en el Viaje por España de Gautier: si el parnasiano llama a Goya en aquel libro "etrange peintre, singulier génie" o "excentrique", Darío no duda en tacharlo de "Poderoso visionario, / raro ingenio temerario...". También señala Marasso muchas similitudes entre el vocabulario artístico que Gautier emplea allí y el de Darío. 
Rodembach (sic), Alberto Samain (sic) y otros grandes galvanizadores de la sentimentalidad humana... ${ }^{27}$

Todavía en 1905 habría de aparecer en las librerías la segunda edición de Los Raros, en cuyo prólogo, y he aquí un detalle muy notable, Darío identificaba por vez primera "modernismo" con "simbolismo", atribuyéndose de paso su implantación en nuestras letras. Quizás Darío no fuese cabalmente simbolista stricto sensu, pero listo sí, y mucho, de ahí que, arrogándose la paternidad del simbolismo hispánico, anduviera previendo por dónde habrían de discurrir los caminos a la modernidad -y a su propia posteridad-: "Todo lo contenido en este libro fue escrito hace doce años, en Buenos Aires, cuando en Francia estaba el simbolismo en pleno desarrollo. Me tocó dar a conocer en América ese movimiento y por ello [...] fui atacado y calificado con la inevitable palabra decadente...".

Un año más tarde, en su artículo "Nuevos poetas de España" -Opiniones (1906)se ratificaría en este juicio, armonizando claramente modernismo y simbolismo a propósito del "movimiento mental que por la influencia del simbolismo francés transformó las letras hispanoamericanas. Ese movimiento, aunque tardío, llegó a España, y dio nueva vida a las letras españolas". A continuación, Darío iría citando a quienes consideraba los poetas españoles más renovadores, y es indudable que sus mayores aplausos los dirigió a aquellos de mayor parentesco con el simbolismo: el primero, Antonio Machado, "quizá el más intenso de todos", al que seguían su hermano Manuel, un "verleniano de la más legítima procedencia", y Ramón Pérez de Ayala, una suerte de Francis Jammes castellano. Por su parte, a Juan Ramón Jiménez ya lo había alabado profusamente en Tierras solares, y ahora se limitó sencillamente a recoger algunos de los juicios que allí emitiera del poeta "más sutil y sentimental" de todos. En cuanto a los que inclinaban su obra del lado parnasiano como Antonio de Zayas, Darío se limitó a encomiar su "vocabulario, su elegancia decorativa, los saltos libres de su Pegaso", para concluir que sus "Sonetos se resienten de heredianos algunos". Y en último lugar dedicaba un breve párrafo a Villaespesa, del que el almeriense no salía muy bien parado: "Enamorado de todas las formas, seguidor de todas las maneras, hasta que se encontró él mismo, si es que se ha encontrado".

Desde 1898, los caminos de Darío y el Parnaso se habían ido separando definitivamente. Sus últimos libros de versos, El canto errante (1907), Poema del otoño y otros poemas (1910) y Canto a la Argentina y otros poemas (1914) poco aportan ya a la vertiente parnasiana de su obra poética. Ello no significa, empero, que Darío renegará absolutamente de los viejos maestros ni de su poesía escrita bajo el influjo de la Escuela, pues todavía en aquellos libros finales incluirá poemas

27 No sería ésta la única ocasión en que el "noventayochista” Manuel Bueno dejara un juicio positivo de la lírica modernista. El 14 de Mayo de 1904 se estrenaba en el Teatro Español de Madrid una adaptación, en prosa y verso, del drama de Banville Gringoire -El juglar, en versión de Camilo Bargiela y Ramón de Godoy-. Bueno escribió para El Heraldo de Madrid -15 de mayo de 1904- la crónica del estreno, y allí aplaudía la factura de la obra y el buen hacer de un Banville dramaturgo que "sueña, sufre, y se queja. Sueña con las quimeras de siempre, con lo que no es y debiera ser, sufre al contacto de las rudezas de la vida, porque el hambre y la miseria no reparan en castigar y humillar al talento, y se queja de que los poderosos no fijen su piedad en las angustias del pobre...". 
parnasianos escritos tanto en su etapa centroamericana como en los últimos años de su vida, así como algunos guiños y homenajes explícitos a quienes seguía considerando entre sus referentes ${ }^{28}$. Lo mismo cabría decirse de su prosa crítica. En Opiniones (1906), y frente a los varios ensayos sobre Moréas, Rollinat o Rémy de Gourmont, no se olvidaría Darío de recordar tras su muerte a uno de los grandes maestros del Parnaso en "Lo que queda de Heredia". El texto no es otra cosa que un alegato en defensa de la Escuela parnasiana y, por supuesto, de una fracción de su propia poesía: "Hay la idea común de que los parnasianos fueron simples artesanos del verso [...]. No hay uno solo de los «impasibles» que no tenga en su estrofa, en la apariencia, fría, un estremecimiento [...]. Se ignorará en lo porvenir a Heredia si se borra por completo la historia de la poesía francesa"29.

Más agridulces serán los recuerdos que con el paso del tiempo le inspirará otro de los grandes ídolos literarios de su juventud, Catulle Mendès. Como motivo de su muerte, el 8 de febrero de 1909, el poeta nicaragüense le dedicaría un extenso y sentido obituario donde lo defendía de los ataques de un sector de la crítica al par que lo rememoraba como a "uno de mis guías espirituales, después del gran Hugo -el pobre Verlaine vino después-; [...] el Mendés cuentista de cuentos encantadores e innumerables, galante, finamente libertino, preciosamente erótico" ${ }^{30}$. De diferente signo, sin embargo, sería la última alusión a Catulle Mendès en la obra de Darío, ubicable en un párrafo de su Autobiografía (1913) en el que el poeta rememora sus primeros tiempos en el París de comienzos del siglo XX de la mano de Gómez Carrillo: "un viejo barrigón, cabeza de nazareno fatigado, todavía con fuertes pretensiones a las conquistas femeninas, las cuales, en efecto, lograba en el mundo de las máscaras, pues era crítico teatral y personaje dominante...". ¿A qué se debía este resquemor contra el personaje Mendès y su trato social? En el precitado

28 Si en la célebre "Epístola a la señora de Leopoldo Lugones" de El canto errante (1907) evocaba, con socarronería, el prosaísmo de Coppée, que nunca fue de su gusto -“A veces me dirijo al mercado, que está / en la Plaza Mayor. (¿Qué Coppée, no es verdá?) / Me rozo con un núcleo crespo de muchedumbre / que viene por la carne, la fruta y la legumbre"-, en Poema del otoño y otros poemas (1910), aparte de incluir como cierre del libro un poema banvillesco, fechado en 1891, "El clavicordio de la abuela", presentaba igualmente un explícito homenaje a Leconte de Lisle y a su poema "Midi" en "Mediodía": "Midi, roi des étes, como cantaba el criollo / Francés...". Y todavía en el último de sus poemarios, Canto a la Argentina y otros poemas (1914) hubo de acordarse de Banville en un "Pequeño poema de carnaval" que, si bien llevaba la fecha de 1912, estaba escrito según la manera funambulesca propia de veinte años antes: "Y ahora, cuando empache / La fiesta, y el apache / Su mensaje despache / A la Alegría vil, / Dará púrpura a Momo / En un divino asomo / Escapada de un tomo / La sombra de Banville...". Por otra parte, en uno de sus cuentos tardíos, "Luz de luna" (1914), Darío reelaboraría sendas composiciones de Banville y de Verlaine. Cf. Sellés, 2002: 150-152.

29 Aún en la prosa "Jardines de Francia” de Parisiana (1908) remembraría una última vez, con emoción lírica, a su divino José María de Heredia, "que desaparece dejando tras sí un rastro luminoso, como esos meteoros que pasan en el firmamento...”.

30 "Catulle Mendès" apareció originalmente en la revista venezolana El Cojo Ilustrado, el 15 de junio de 1909, y fue recogido más tarde en Letras (1911). En ese mismo volumen de Letras intercaló Darío una reseña, "En el país de Bohemia", sobre el drama que Catulle Mendès dedicara a la figura de Glatigny. Darío evoca allí al más bohemio de los parnasianos en lo que viene a significar uno de los escasos textos hispánicos que se ocupan del olvidado poeta: "príncipe y fauno de un cuento improbable, es un personaje de ayer no más, de carne y hueso; [...] Glatigny vivió en un tiempo de entusiasmo que hoy nos parece tan lejano, y exprimió el jugo de sus Viñas locas y lanzó, lleno de un fuego apolíneo, sus Flechas de oro. No pensó nunca en el mañana (...): la Gloria, ella no, no le olvidó". Se trataba de la segunda vez que Rubén Darío mentase a Glatigny: antes lo hizo en su artículo sobre Lugones "Un poeta socialista" -El Tiempo, 18 de mayo de 1896-. En cuanto al drama de Mendès, Darío no le escatimaba elogios: "Es, indudablemente, un gran virtuoso; pero es también, indudablemente, un grande y magnífico poeta...". 
obituario, Darío había afirmado, un tanto misterioso, que "yo no le traté personalmente, y vale más". Quizás tuviera, realmente, un encuentro con Mendès del que no guardase grata memoria...

Con este amargo desencanto se cierra uno de los círculos concéntricos, el parnasiano, del Darío poeta. El final del hombre es de sobras conocido: los viajes, la enfermedad, la terrible agonía y la muerte en su Nicaragua natal el 6 de febrero de 1916, dejando para la posteridad un legado literario que todavía hoy merece la consideración de la crítica y los lectores. Un legado que supo ser, a su debido tiempo y libro y poema, romántico, parnasiano, decadente, simbolista y, en fin, modernista mayor. Así lo recuerdan los innumerables manuales, artículos, ensayos y libros monográficos que su obra ha inspirado y seguirá inspirando en el seno de la historiografía literaria de la Hispanidad. Quedémonos con un poeta que supo evolucionar y revolucionar la poesía española, orientadas sus velas a los vientos de la modernidad, ora a los cierzos y las trombas románticas, ora a los ábregos y alisios parnasianos o por último al mistral simbolista, siempre rumbo al porvenir. Quedémonos con un Darío proteico, heterogéneo, y en todo caso único. Quedémonos, en fin, con las brillantes palabras que le dedicara su compatriota y amigo Santiago Argüello (1935: 37):

Tras el Rubén romántico, el Rubén parnasiano. Tras de Musset y Hugo, Catulle Mendès y de Lisle. La evolución del alma poética de Rubén Darío va ondulando a la par con la francesa evolución. Y a la par también se van abriendo las pestañas de nuestro continente al sentimiento lírico de su liberación. [...] Aires de otra parte. Y en vez de aquellos nombres del terruño, Leconte de Lisle, Armand Silvestre, Catulle Mendès, Leon Dierx... ¡Ya hay algo más, amigos, que los castaños del solar! [...] Darío fue romántico con los románticos; parnasiano con los parnasianos; decadente y simbolista con los simbolistas y decadentes; francés con los franceses, español con los españoles; y renacentista y pagano y oriental y... ¡todo!".

\section{Referencias bibliográficas}

Argüello, Santiago. Modernismo y modernistas. 2 tomos. Guatemala: Tipografía Nacional, 1935.

Banville, Théodore de. Oeuvres. I. Odes funambulesques. II. Les Stalactites. Odelettes. Amethystes. Le Forgeron. III. Occidentales. Rimes doreés. Rondels. La Perle. IV. Idylles prusiennes. Riquet à la houppe. V. Les Cariatides. Roses de Noël. VI. Le sang de la coupe. Trente-six ballades joyeuses. Le Baiser. VII. Les Exilés. Les Princesses. Reimpresión de la edición de París, 1890-1909. Genève. París: Slatkine Reprints, 1972.

-Petit traité de poésie française. Edición facsímil de la obra publicada por G. Charpentier en 1883. París: Ressouvenances, 1998.

Baudelaire, Charles. Le Spleen de Paris. Petits Poèmes en prose. Édition de Robert Kopp, intr. de Georges Blin. Paris: Gallimard, 2006.

Bueno, Manuel, "Poetas americanos. Rubén Darío", El heraldo de Madrid, 26 de junio de 1905.

Carilla, Emilio. Una etapa decisiva de Dario (Rubén Darío en la Argentina). Madrid: Gredos, 1967. 
Carter, Boyd G. -Las revistas literarias de Hispanoamérica. Breve historia y contenido. México: Ed. De Andrea, 1959.

- La "Revista de América" de Rubén Darío y Ricardo Jaimes Freyre. Managua: Publicaciones del Centenario de Rubén Darío, 1967.

- Historia de la literatura hispanoamericana a través de sus revistas. México: Ed. De Andrea, 1968.

Darío, Rubén. Obras Completas. 22 tomos. Madrid: Ed. Mundo Latino, 1917-1919.

-Obras Completas. 5 Tomos. Madrid: Afrodisio Aguado, 1950-1955.

-Obras Completas. Volumen I: Poesía. "Opera Mundi”. Barcelona: Galaxia Gutenberg/Círculo de Lectores, 2007.

- Prosas profanas. Pról. de Antonio Gamoneda. Álbum de Arturo Ramoneda. Madrid: Alianza Editorial, 1998.

-Los raros. Zaragoza: Libros del Innombrable, 1998.

- Autobiografía. España contemporánea. México: Ed. Porrúa. México, 1999.

- El modernismo y otros ensayos. Ed. de Iris M. Zavala. Madrid: Alianza Editorial, 1989.

Diaconescu, A. Ma ., “¿Parnasiana o simbolista? Estudio comparativo de la «Sinfonía en gris mayor» de Rubén Darío", Anales de Literatura Hispanoamericana, II-III (1973-1974), pp. 791-810.

Díez Canedo, E., "La poesía castellana y Rubén Darío”, España, n 56, 17 de febrero de 1916.

Díez-Canedo, E. y F. Fortún (eds.). La poesía francesa moderna. Madrid: Renacimiento, 1913.

Dolinescu M., "Parnassianismul. Le Parnasse”, Bulletin d'études parnassiennes, $\mathrm{n}^{\circ} 6$ (junio 1984), p. 40

Englekirk, J. E., "La literatura y la revista literaria en Hispanoamérica", Revista Iberoamericana, $\mathrm{n}^{\mathrm{o}}$ 51, 52, 53 y 55 (1961-63).

Faurie, M.-J. Le modernisme hispano-américain et ses sources françaises. Paris: Centre de Recherches de 1'Institut d'Études Hispaniques, 1966.

Gautier, Théophile. -Oeuvres poétiques complètes. Edición establecida por Michel Brix. Paris: Bartillat, 2004.

-Oeuvres. Choix de romans et contes. Edición establecida por Paolo Tortonese. Paris: Collection "Bouquins". Robert Laffont, 1995.

Gómez Carrillo, Enrique. Sensaciones de París y de Madrid. Paris: Garnier Hermanos, Editores, 1900.

González Salvador, Ana, "Introducción” a Maeterlinck, M. La intrusa. Los ciegos. Pelléas y Mélisande. El pájaro azul. Madrid: Cátedra, 2000.

Groussac, Paul, "Boletín Bibliográfico. Los Raros, por Rubén Darío", La Biblioteca, n 7 , noviembre de 1896.

—_Boletín Bibliográfico. Prosas profanas, por Rubén Darío”, La Biblioteca, n 9, enero de 1897.

—Rubén Darío", Nosotros, Buenos Aires (febrero de 1916), pp. 40-47.

Henríquez Ureña, Max, "Poetas cubanos de expresión francesa", Revista Iberoamericana, $n^{\circ} 6$ (mayo de 1941), pp. 301-344.

Heredia, José María de. Les Trophées. Ed. de Anny Detalle. Paris: Gallimard, 1981.

Lafleur, Héctor René, Sergio D. Provenzano y Fernando Pedro Alonso. Las revistas literarias argentinas (1893-1960). Buenos Aires: Ediciones Culturales Argentinas, 1962.

Leconte de Lisle, Charles. Poèmes antiques. Edición de Claudine Gothot-Mersch. Paris: Gallimard, 1994.

-Poèmes barbares. Edición de Claudine Gothot-Mersch. Paris: Gallimard, 1985.

Maiorana, M. T., "Rubén Darío et le mythe du centaure", L'Amitié guérinienne (eneromarzo de 1959), pp. 1-23 
Mapes, Erwin K. L'influence française dans l'oeuvre de Rubén Dario. Paris: Librairie Ancienne Édouard Champion, 1925.

Marasso, Arturo. Rubén Dario y su creación poética. Buenos Aires: Editorial Kapelusz, 1973.

Marini-Palmieri, Enrique. El Modernismo literario hispanoamericano. Caracteres esotéricos en las obras de Darío y Lugones. Buenos Aires: Ed. Fernando García Cambeiro, 1989.

Ménard, Louis. Rêveries d'un païen mystique. Paris: Ed. Georges Crès et Cie., 1911.

Mendès, Catulle. Les poésies: Philoméla, Sonnets, Pantéleïa, Sérénades, Pagode, Soirs moroses, Contes épiques, Hespérus, Interméde, Le Soleil de Minuit. Paris: P. Ollendorff, 1885.

-La Légende du Parnasse contemporain. Bruselas: Brancart, 1884. Ed. facsímil en Ginebra-Paris: Slatkine Reprints, 1983.

—Lieds de France, avec 10 musiques de Alfred Bruneau et 10 dessins de Raphaël Mendès. Paris: Marpon \& Flammarion, 1892.

Rodó, J. E. Hombres de América. Discursos parlamentarios. Barcelona: Editorial Cervantes, 1924.

Segovia, Tomás (pról. y notas). Gérard de Nerval. Poesía y prosa literaria. Barcelona: Galaxia Gutenberg, Círculo de Lectores, 2004.

Sellés, Carmen Luna. La exploración de lo irracional en los escritores modernistas hispanoamericanos. Literatura onírica y poetización de la realidad. Santiago de Compostela: Universidade de Santiago de Compostela, 2002. 